\title{
Isolation Blue Green Algae from Maize Fields of Mohol Tahasil in Solapur
}

\author{
Seema Khadatare ${ }^{1}$, D. S. Suryawanshi ${ }^{2}$ \\ ${ }^{1,2}$ Department of Botany, Jawahar Arts, Science and Commerce College, Andur, Tal. Tuljapur, Dist. Osmanabad
}

\begin{abstract}
Fertility of soil is important for the productivity of crop plants. It has been suggested that blue-green algae (BGA) assist higher plant growth by supplying growth substances. Blue green algae are a group of microalgae that can fix the atmospheric nitrogen which is important for the fertility of soil. Isolation of these cyanobacteria from natural sources in pure form is essential step for their efficient use as biofertilizer. In present investigation four species of blue green microalgal forms are isolated from soil samples from maize fields of Mohol tehsil of Solapur district. The isolation of pure cultures were done by selecting a single colony from mix cultures grown on selected media like BG-11, bold basal media, ASN III media as different BGA strains can grow on different media. The same media in solid form is used for further purification and sub culturing. The pure cultures were then transferred in solid and liquid media for further studies.
\end{abstract}

Keywords: Blue green Algae, Cyanobacteria, biofertilizer,

\section{Introduction}

Cyanobacteria represent a small taxonomic group of photosynthetic prokaryotes which some of them are able to $\mathrm{N}_{2}$ fixation and also possess a tremendous potential for producing a wide range of secondary metabolites. Cyanobacteria have drawn much attention as prospective and rich sources of biologically active constituents and have been identified as one of the most promising groups of organisms capable of producing bioactive compounds (Fish \& Codd 1994, Schlegel et al. 1999). Production of bioactive molecules such as auxins, production of secondary metabolites linked to bio control of bacterial and fungal diseases as well as improving soil structure and porosity through secretion of polysaccharides aiding in soil aggregation are the most important functions of these microorganisms (Karthikeyan et al. 2007).

De (1939) attributed the natural fertility of maize field soil and its maintenance to the process of biological nitrogen fixation by cyanobacteria. This was the first report, which recognized the agronomic potential of cyanobacteria in India. The widespread application of single element fertilizers (especially $\mathrm{N}$ in Asian countries) in the cultivation of major crops has led to accelerated exhaustion of other major and minor nutrients leading to nutrient imbalances and poor soil fertility. In the current scenario therefore, an urgent need has been felt to deploy microbial bio-fertilizer which are multifaceted such as cyanobacterial biofertilizer. As yet for substitution of chemical fertilizers by microbial bio fertilizers many studies have been done. Gupta \& Shukla (1967) studied the algal influence on growth, yield and protein content of maize plants and showed that pre-soaking maize seeds with BGA cultures or extracts enhances germination, promotes the growth of roots and shoots, and increases the weight and protein content of the grain.

Svircev et al. (1997) also reported that plant growth was enhanced in the presence of cyanobacterium, even without organic $\mathrm{N}$ fertilizer application. Beneficial effects of cyanobacterial inoculation were reported, not only for maize, but for other crops such as wheat, soybean, oat, tomato, radish, cotton, sugarcane, chili, bean, muskmelon and lettuce (Venkataraman 1972, Thajuddin \& Subramanian 2005, Maqubela et al. 2008, Karthikeyan et al. 2007). Several reasons have been proposed for beneficial effects of cyanobacteria on the growth of different plants.

Additionally, cyanobacteria excrete complex organic carbon compounds that bind to the soil particles and improve soil aggregation, hence improve soil structure, soil permeability and water holding capacity of soil (Kaushik 2007). However, to date, the effect of single species cyanobacteria biofertilizer on plant growth has not yet been fully investigated. The primary aim of this research was to study cyanobacteria species isolated from soil of maize fields of Mohol tehsil of Solapur district.

\section{Materials and Methods}

\section{Collection of Soil Sample}

Soil samples were collected from the depth of $0-5 \mathrm{~cm}$ on several maize fields in Mohol tahasil of Solapur district of Maharashtra. (Rangaswamy 1996).

\section{Isolation of Blue Green Algae:}

Soil samples were transferred to sterile Petri dishes and added to them sterilized BG-11 medium with $\mathrm{pH}$ : 7.1. The Petri dishes were placed in a culture chamber at $25^{\circ} \mathrm{C}$ and a 12/12 h light dark cycle at artificial illumination (2000-2500 Lux) for two weeks. After colonization, for purification, identification and multiplication of colonies, a part of each colony was removed by a loop and transferred to a new plate. After purification of taxa, taxonomic determination was carried out by light microscopy and based on Desikachary (1959), Prescott (1970) and Wehr et al. (2002), and corrected based on algae base website (www.algaebase.org).

\section{Experimental Results}

\section{Pure Cultured Algal Samples}

Following four pure cultured strains of algae are obtained Identification was done by using morphological characters, 


\section{International Journal of Science and Research (IJSR) \\ ISSN (Online): 2319-7064}

Index Copernicus Value (2013): 6.14 | Impact Factor (2015): 6.391

thallus structure and colony characters considered as diagnostic feature for identification and these morphological structures were identified by the standard Desikachary 1959 and some other books and various research articles.

\section{Gloecapsa sp.:}

Class: Cyanophyceae; Order: Chlorococcales; Family: Microsystaceae The colonies of Gloecapsa starts to growing generally after third day of inoculation. The pure culture of Gloecapsais observed as heavy green mass generally settles down at the bottom of media. It is mucilaginous, compact, cells are spherical, having 3-4 $\mu$ diameter. Blue green in colour. The cells are having sheath very thick as thick as protoplast, very distinctly any many times lamellated (Desikachary 1959).(Pate-A)

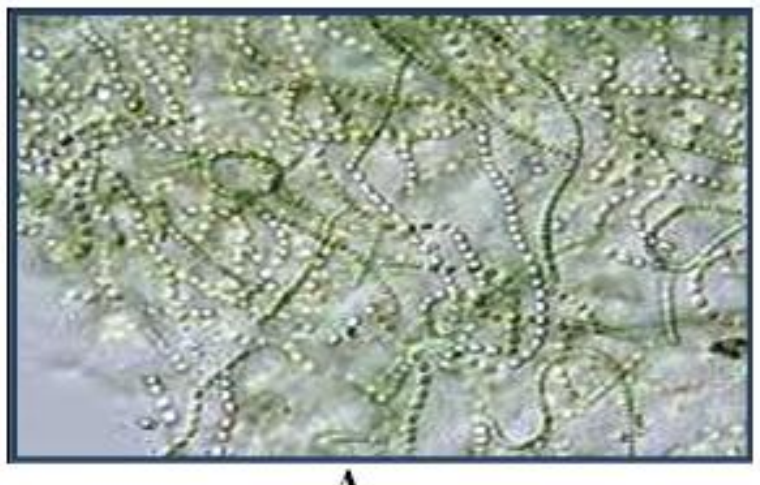

A

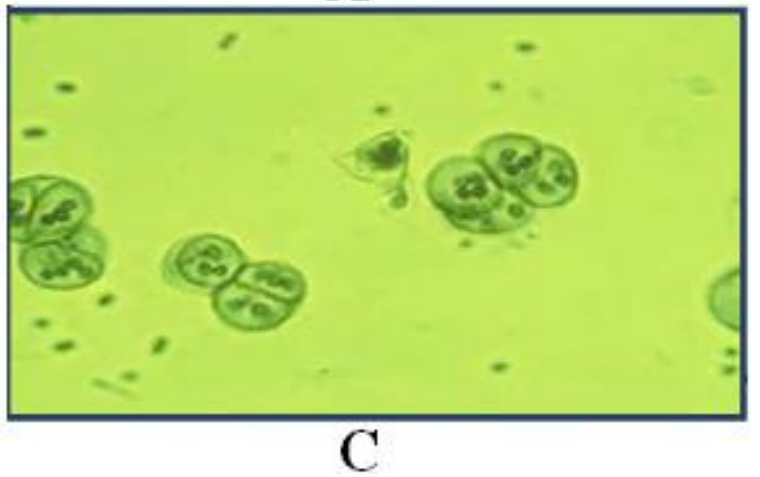

\section{Oscillatoria sp.:}

Class: Cyanophyceae; Order: Oscillatoriales; Family: Oscillatoriaceae Phormidiumstarts to grow after fifth day of inoculation on the plates. In the form of pure culture Oscillatoria appears like bluish green sticky mass which settles down in the media. In this algae trichomes are blue green, more or less brownish, violet or reddish, mostly forming a thallus, mostly straight, not constricted at the cross wall, $16-60 \mu$ broad, commonly $25-50 \mu$, blue green to dirty green, slightly or briefly attenuated at the apices and bent; cells 1/11-1/4 as long as broad, 3.5-7 $\mu$ long; end cells flatly rounded, slightly capitate without or with slightly thickened membrane (Desikachary 1959). ).(Pate-C)

\section{Phormidium sp.:}

Class: Cyanophyceae; Order: Oscillatoriales; Family: Oscillatoriaceae. The colonies of Phormidium start to grow slowly as compared to Gloecapsa. Pure culture of Phormidium in the flask appears in the form of bluish green lumps which generally floats on the surface of media.Itis more or less expanded, bright blue green. It is filamentous,

\section{Nostoc sp:}

Class: Cyanophyceae; Order: Nostocales; Family: Nostocaceae. Nostoc, genus of blue-green algae with cells arranged in beadlike chains that are grouped together in a gelatinous mass. Ranging from microscopic to walnut-sized, masses of Nostoc may be found on soil and floating in quiet water. Reproduction is by fragmentation. A special thickwalled cell (akinete) has the ability to withstand desiccation for long periods of time. After 70 years of dry storage, the akinete of one species germinates into a filament when moistened. Like most blue-green algae, Nostoc contains two pigments, blue phycocyanin and red phycoerythrin, as well as chlorophyll, and has the ability to fix nitrogen in specialized cells called heterocysts. A terrestrial species has been used as a supplementary food source in Asia ).(Pate-B)

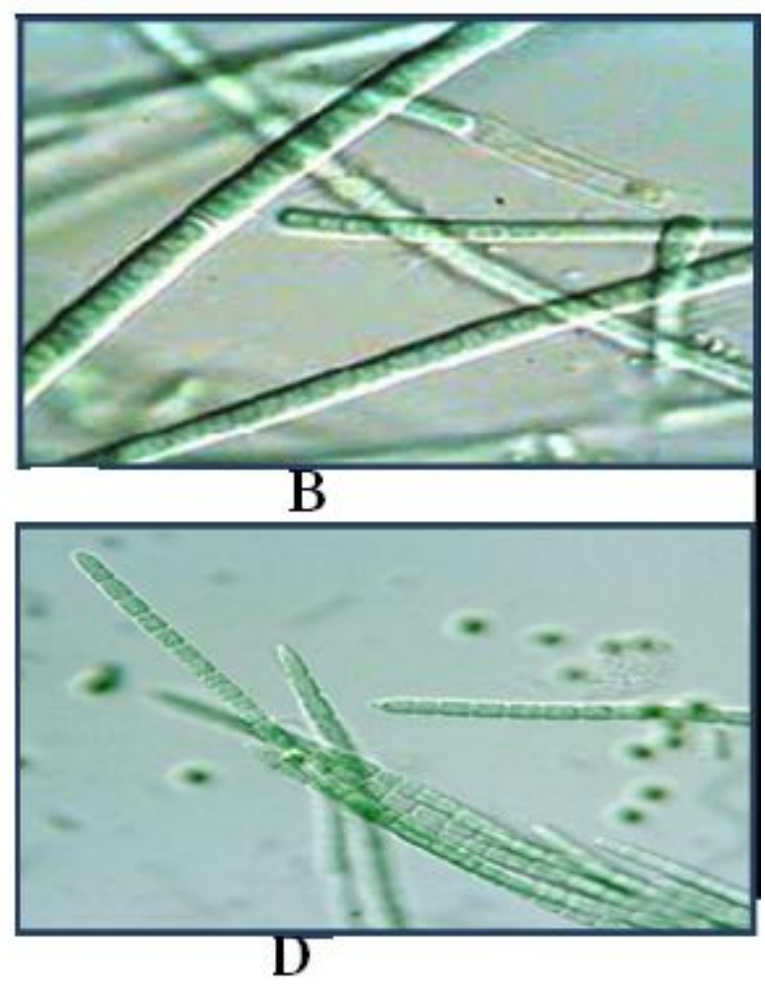

variously entangled, having thin sheath, firm or diffluent sometimes thick and more or less lamellate, violet coloured. Generally cells are shorter than broad, 1.5-2.71 $\mu$ long, rarely granulated at the cross wall, end cell rounded, calyptra absent (Desikachary 1959). ).(Pate-D)

\section{Conclusion}

Blue green algae are used in various branches of science and technology. In present investigation four different strains of cyanobacteria namely Gloecapsa, Nostoc Oscillatoria, Phormidium were cultured. Algal strains are isolated in axenic culture by the improved antibiotic method using streptomycin and fluconazole. Biodiversity of these blue green algae has been studied by different workers like Debnath (2009) from west Bengal studied diversity of Phormidium, Oscillatoria, Gloecapsa have been studied by Biban and Singh (2011) from kurukshetra. While very less work has been carried out on pure culturing of cyanobacteria from maize fields. The cultures in the flask are formed in light green to dark blue green in colour. Identification and

\section{Volume 5 Issue 6, June 2016} www.ijsr.net 


\section{International Journal of Science and Research (IJSR) \\ ISSN (Online): 2319-7064 \\ Index Copernicus Value (2013): 6.14 | Impact Factor (2015): 6.391}

culture of Blue green algae is necessary to study soil fertility and productivity of crop plants such as Maize.

\section{Acknowledgement}

Authors are thankful to Principal, Jawahar Arts, Science and Commerce College, Andur, Tal. Tuljapur, Dist. Osmanabad for providing laboratory facilities to carry out the research work.

\section{References}

[1] Biban L. and Singh C. B. (2011). Dominant cyanobacterial flora of the religious ponds at Holy Geet's birthplace kurukshetra, India. Journal of research in biology. 8: 609 - 616

[2] De, P.K. 1939. The role of blue-green algae in nitrogen fixation in rice fields. Proceeding of the Royal Society of London. Series B 127: 121-139.

[3] Debnath M., Mandal N. C. and Ray S. (2009). The study of cyanobacterial flora from geothermal springs of Bakreaswar, West Bengal, India. Algae 24(4): 185 - 193

[4] Desikachary, T.V. 1959. Cyanophyta. New Delhi: Indian Council of Agricultural Research. 686 pp.

[5] Fish, S.A. \& Codd, G.A. 1994. Bioactive compound production by thermophilic and thermo tolerant cyanobacteria (blue-green algae). World Journal of Microbiology and Biotechnology 10:338-347.

[6] Gupta, A. B., and Shukla, A. C., L. J. Sci. and Tech. Ind., 2 (3), 404 (1967).

[7] Karthikeyan, N., Prasanna, R., Nain, L. \& Kaushik, B.D. 2007. Evaluating the potential of plant growth promoting cyanobacteria as inoculants for wheat. European Journal of Soil Biology 43: 23-30.

[8] Kaushik, B.D. 2007. Cyanobacterial biofertilizer technology. Pp. 53-59. In: S. Kannaiyan, K. Kumar \& K. Govindarajan (eds). Biofertilizers technology. Scientific Publishers. India.

[9] Maqubela, M.P., Mnkeni, P.N.S., Malamissa, O., Pardo, M.T. \& Acqui, L.P.D. 2008. Nostoc cyanobacterial inoculation in South African agricultural soils enhances soil structure, fertility and maize growth. Plant and Soil 315: 79-92.

[10] Prescott, G.W. 1970. Algae of the western great lakes area. WM. C. Brown Company Publishers. 977 pp.

[11] Rangaswamy, G. 1996. Agricultural microbiology. Asia Publishing House, Bombay, p. 54-76.

[12] Singh, P.K. 1988. Biofertilization of rice crop. pp. 109114. In: S.P. Sena. \& P.C. Palit (eds). Biofertilization polentialities and problems. Plant Physiology Forum.

[13] Svircev, Z., Tomas, I., Nenin, P. \& Drobac, A. 1997. Co-cultivation of N2-fixing cyanobacteria and some agriculturally important plants in liquid and sand culture. Applied Soil Ecology 6: 74-81.

[14] Thajuddin, N. \& Subramanian, G. 2005. Cyanobacterial biodiversity and potential application in biotechnology. Current Science 89: 47-57.

[15] Venkataraman, G.S. \& Neelakantan, S. 1967. Effect of the cellular constituents of the nitrogen fixing bluegreen algae Cylindrospermum muscicola on the root growth of rice seedlings. Journal of General and Applied Microbiology 13: 53-61.
[16] Venkataraman, G.S. 1972. Algal biofertilizer and rice cultivation. Today and Tomorrows Printer and Publishers. New Delhi. 71 pp.

[17] Wehr, J.D., Sheath, R.G. \& Thorp, J.H. 2002. Freshwater algae of North America: Ecology and classification. Aquatic Ecology Press. 917 pp.

\section{[18] http://www.algaebase.org}

